\title{
Low occurrence of occult hepatitis B virus infection and high frequency of hepatitis $C$ virus genotype 3 in hepatocellular carcinoma in Brazil
}

\author{
R.S.M. Alencar ${ }^{1}$, M.M.S. Gomes ${ }^{1,3}$, R. Sitnik ${ }^{4}$, J.R.R. Pinho ${ }^{1,3,4}$, F.M. Malta ${ }^{1,3}$, \\ I.M.V.G.C. Mello ${ }^{3,5}$, E.S. Mello², T. Bacchella1, M.C.C. Machado', V.A.F. Alves ${ }^{2}$ and \\ F.J. Carrilho ${ }^{1}$
}

1Departamento de Gastroenterologia, 2Departamento de Patologia, Faculdade de Medicina, ${ }^{3}$ Laboratório de Gastroenterologia e Hepatologia Tropical, Instituto de Medicina Tropical de São Paulo, Universidade de São Paulo, São Paulo, SP, Brasil, "4Departamento de Patologia Clínica, Hospital Israelita Albert Einstein, São Paulo, SP, Brasil, ${ }^{5}$ Laboratório de Imunologia Viral, Instituto Butantan, São Paulo, SP, Brasil

Correspondence to: J.R.R. Pinho, Instituto de Medicina Tropical, Av. Dr. Enéas C. Aguiar, 470, 05508-000 São Paulo, SP, Brasil

Fax: +55-11-3064-5132. E-mail: jrrpinho@usp.br

Occult hepatitis B virus (HBV) infection has been reported among patients with hepatitis C virus (HCV) infection and hepatocellular carcinoma (HCC). Our aim was to evaluate the presence of occult HBV infection in patients with HCV-related liver cirrhosis (LC) with or without HCC in São Paulo, Brazil. Serum and liver tissue samples from 50 hepatitis B surface antigennegative patients with HCV-related LC who underwent liver transplantation at the University of São Paulo School of Medicine Hospital from 1993 to 2004 were divided into groups with LC only $(\mathrm{N}=33)$ and with LC plus HCC $(\mathrm{N}=17)$. HBV DNA was assayed for serum and paraffin-embedded liver tissue (tumoral and non-tumoral) using real time PCR and only 1 case with HCC had HBV DNA-positive serum. All liver samples were negative. HCV genotype 3 was detected in 17/39 (43.7\%) cases. In conclusion, using a sensitive real time PCR directed to detect HBV variants circulating in Brazil, occult hepatitis B infection was not found among HCV-positive cirrhotic patients and was rarely found among HCV-positive HCC patients. These results are probably related to the low prevalence of HBV infection in our population. Furthermore, we have also shown that HCV genotype 3 is frequently found in Brazilian cirrhotic patients, particularly when they also have HCC. More studies involving a large number of cases should be carried out to confirm these data and to further characterize Brazilian HCV genotype isolates to elucidate genetic features that might be related to its carcinogenic potential.

Key words: Hepatitis C virus; Occult hepatitis B; Hepatocellular carcinoma; HCV genotypes

Research supported by the Alves de Queiroz Family Fund for Research and FAPESP (No. 2000/11457-3).

Received December 15, 2006. Accepted September 17, 2007

\section{Introduction}

Hepatitis B virus (HBV) infection is generally determined by the detection of viral specific antigens and antibodies (hepatitis B surface antigen, HBsAg; hepatitis B e antigen, $\mathrm{HBeAg}$; anti-hepatitis $\mathrm{B}$ core antigen, anti-HBc), and viral DNA (HBV DNA) in serum. In some patients that do not have detectable HBsAg in serum, HBV DNA can be detected in serum or liver samples and their condition is defined as occult or cryptic hepatitis B. Occult HBV infection has been found among patients with hepatitis C, HIV infection, hepatitis non-A-E, and hepatocellular carcinoma (HCC) (1).

Several mechanisms have been considered for occult 
infections by HBV such as low HBV DNA and HBsAg levels (2), mutations in HBV DNA sequence (3), viral DNA integration in the host genome (4), infection of peripheral blood mononuclear cells (5), production of immune complexes containing HBV (6), altered host immune response (7), and interference of other viruses (mainly hepatitis $C$ virus, HCV) (8-15).

Occult HBV infection has been demonstrated in chronic hepatitis patients infected with $\mathrm{HCV}$, being associated with a moderate intra-hepatocyte HBV DNA level (9) and a low frequency of infected cells (10). These results suggest that occult HBV infection may interfere with the clinical picture of chronic HCV infection, accelerating its evolution to cirrhosis (11). Evidence for previous HBV infection even in the absence of HBV DNA detection has been related to the severity of the disease in anti-HCV-positive chronic hepatitis patients (12) but these results were not confirmed by other investigators (13-15).

Occult HBV has been associated with more advanced fibrosis/cirrhosis and with a poor response to interferon (8), but not in all studies. Cirrhosis is considered to be the most important risk factor for HCC. Therefore, besides having a possible direct oncogenetic effect, occult HBV infection may increase neoplastic transformation in HCV-infected patients $(4,8)$. The oncogenicity of occult HBV infection is related to the transactivating role of the $\mathrm{HBx}$ protein and to the ability of HBV to integrate the host genome $(16,17)$. Indeed, some studies have shown that HBV DNA could be detected in HBsAg-negative patients with $\operatorname{HCC}(18,19)$.

The frequency of diagnosis depends on the relative sensitivity of both HBsAg and HBV DNA assays as well as on the prevalence of HBV infection in the population (20). In Brazil, HBV prevalence is variable, since this is a large country with high cultural, ethnic and social diversity. Most Brazilian regions show intermediate endemicity ranging from 1 to $2 \%$ in studies with healthy populations and blood donors. The Southwest region of Paraná State and some indigenous populations of the Amazon Basin (North region) show HBsAg rates around $8 \%$ (high endemicity) (21). HBV seroprevalence is higher among males than females and $\mathrm{HBV}$ is two times more frequent in low socio-economic level populations (21).

Few studies have addressed the presence of occult HBV infection in Brazil. In Rio de Janeiro, it was found in 16 (13.9\%) of 115 HBsAg-negative, anti-HIV- and anti-HBcpositive patients (22), while in Campinas, it was found in $4 \%$ of blood donors, $3.4 \%$ of HIV-co-infected patients and in $24.0 \%$ of anti-HCV-positive patients (23). On the other hand, another study did not find any HBV DNA-positive case among 105 hepatitis $C$ and non-A-E patients followed in São Paulo (24).
The aim of the present study was to determine the occurrence of occult HBV infection in cirrhotic HCV patients with or without concomitant $\mathrm{HCC}$ and the distribution of HCV genotypes among these cases.

\section{Patients and Methods}

\section{Patients}

We analyzed serum and liver explant samples from 50 HCV-infected cirrhotic patients with or without HCC, submitted to liver transplantation. Patients were divided into two groups: group 1, HCV-infected patients with liver cirrhosis ( $\mathrm{N}=33$ ), and group 2, HCV-infected patients with liver cirrhosis and $\mathrm{HCC}(\mathrm{N}=17)$.

Serum samples were collected just before liver transplantation at the Hospital das Clínicas, University of São Paulo School of Medicine, during the period from 1993 to 2004 and were stored at $-20^{\circ} \mathrm{C}$.

\section{Liver explants}

Liver explants were analyzed by a specialized pathologist. Macroscopic examination was carefully carried out to determine the extent and morphology of liver lesions. The number and size of nodules were recorded. Sections of non-tumoral and tumoral liver tissues were stored in formaldehyde for histopathological analysis of the lesions and for further analysis of HBV DNA by PCR. All paraffinembedded tissue samples were analyzed according to the Edmondson and Steiner Classification (25) to evaluate the grade of HCC differentiation.

\section{Clinical data}

The clinical data of all 50 patients were retrospectively reviewed in order to collect information about previous laboratory tests (aspartate aminotransferase; alanine aminotransferase; $\gamma$-glutamyl transpeptidase; alkaline phosphatase; total bilirubin, albumin, creatinine, $\alpha$-fetoprotein, prothrombin time expressed as international normalized ratio) and clinical (ascites and hepatic encephalopathy) and demographic (gender and age) data. Patients were classified according to MELD scores (26) and to the ChildTurcot Classification modified by Pugh (27).

\section{Serological tests}

All patients in this study were tested and found to be anti-HCV seropositive and HBsAg seronegative. Serological markers for HBV (HBsAg, anti-HBc, and anti-HBs) and $\mathrm{HCV}$ (anti-HCV) infection were confirmed in stored serum samples from all patients. All serological markers were determined by immunoenzymatic assays (ELISA, Abbott Laboratories, North Chicago, IL, USA). 
Hepatitis $C$ virus detection and genotyping

Viral RNA was extracted from $100-\mu \mathrm{L}$ serum samples using the guanidine isothiocyanate-phenol-chloroform method, as previously described (28). The 5 ' untranslated region of the HCV genome was amplified and positive samples were determined by agarose gel electrophoresis.

PCR products were submitted to cycle sequencing reactions using dideoxynucleotides with fluorescent markers (ABI Prism ${ }^{\circledR}$ BigDye $^{\mathrm{TM}}$ Terminator Cycle Sequencing Ready Reaction Kit, Applied Biosystems, Foster City, CA, USA). Genotyping was carried out by aligning both sequenced strands (sense and antisense) and the resulting consensus sequence was compared with a database (29).

\section{Hepatitis B virus detection}

HBV DNA was extracted from $200-\mu \mathrm{L}$ serum samples using the QIAamp DNA mini-kit (Qiagen, Hilden, Germany) and eluted in $50 \mu \mathrm{L}$. Paraffin-embedded liver tissue was cut into $10-\mu \mathrm{m}$ sections and the slides were cleared with xylene. DNA was then extracted using the same kit as for the serum samples and its quality was tested by PCR amplification of the $\beta$ actin gene as described by Dakhama et al. (30).

HBV DNA was detected by a real time PCR (RT-PCR) assay developed by us. Primers and the TaqMan probe for amplification and detection of the $S$ gene region of $\mathrm{HBV}$ were chosen using the Primer Express program (Applied Biosystems) based on $62 \mathrm{HBV}$ sequences from a previous paper describing HBV genotypes among Brazilian patients (31). Primers and probe sequences utilized were HBV362F $5^{\prime}$ CCT GGY TAT CGY TGG ATG TGT - 3'; HBV477R 5' - GGA CAV ACG KGC AAC ATA CCT T - 3'; HBV419T 5' - FAM CTA TGC CTC ATC TTC TT - 3' - MGB. In the present assay, we used a $50-\mu \mathrm{L}$ mix containing $1 \mathrm{X}$ TaqMan Universal PCR Master Mix, $20 \mu \mathrm{M}$ of each primer and a TaqMan probe (FAM probe), 1X IPC Mix (VIC probe), 1X IPC DNA and $5 \mu \mathrm{L}$ of extracted sample. All reagents and kits were from Applied Biosystems. Absolute quantification of HBV DNA was carried out with an $A B I P R I S M 7500$ real time analyzer using universal cycling conditions. The detection limit for RT-PCR was $50 \mathrm{IU} / \mathrm{mL}$. This method was validated by comparison with results obtained from Quest Diagnostics (Sonora, CA, USA) and from a nested HBV DNA PCR protocol carried out by our group (32).

\section{Statistical analysis}

Statistical analysis was performed with the SPSS Software, version 12. Data were analyzed by the chi-square test, likelihood ratio, Fisher exact test, Student $t$-test, and Mann-Whitney test, when needed (33).

\section{Results}

\section{Demographic and clinical data}

Group 1 consisted of 21 men and 12 women with a median age of $53.7 \pm 8.6$ years, and group 2 consisted of 13 men and 4 women with a median age of $59.5 \pm 5.7$ years $(P=0.3770$ and 0.0029 , respectively).

Child-Turcot classification modified by Pugh was: group $1=$ child $A: 0, B: 17$, and $C: 16$ patients; group $2=$ child $A$ : 4, B: 7 , and $C: 6$ patients $(P=0.0090)$, and MELD score was: group $1=13.80 \pm 5.03$; group $2=12.5 \pm 6.33(P=$ 0.3730).

Initial forms of HCC cell differentiation were more frequent, according to the Edmondson and Steiner (25) Classification: grade I $=2(11.7 \%)$, grade $I I=11(64.7 \%)$, and grade III = $4(23.5 \%)$. Nodules of less than $3.0 \mathrm{~cm}(15$; $88.2 \%)$ were also more frequent than nodules of 3.0-5.0 $\mathrm{cm}(2 ; 11.7 \%)$.

\section{Laboratory results}

Table 1 summarizes the biochemical and coagulation results for both groups of patients. None of the variables showed statistically significant differences between the two groups.

Since the standard deviation was very high for $\alpha$ fetoprotein, its results were stratified into grades: $I=0-9$ $\mathrm{ng} / \mathrm{mL}, \mathrm{II}=10-99 \mathrm{ng} / \mathrm{mL}$, and $\mathrm{III}=\geq 100 \mathrm{ng} / \mathrm{mL}$ (Table 2). Stratified data analysis did not show a statistically significant difference $(P=0.49)$.

Results of the serological HBV markers are shown in Table 3.

Table 1. Biochemical and coagulation data for HCV-infected patients with liver cirrhosis with and without hepatocellular carcinoma (HCC).

\begin{tabular}{lcc}
\hline Variable & $\begin{array}{c}\text { Without HCC } \\
(\mathrm{N}=33)\end{array}$ & $\begin{array}{c}\text { With HCC } \\
(\mathrm{N}=17)\end{array}$ \\
\hline AST $(\mathrm{U} / \mathrm{L})$ & $71.9 \pm 40.6$ & $80.0 \pm 67.2$ \\
ALT $(\mathrm{U} / \mathrm{L})$ & $64.2 \pm 40.7$ & $72.1 \pm 61.8$ \\
GGT $(\mathrm{U} / \mathrm{L})$ & $157.9 \pm 192.1$ & $86.7 \pm 96.9$ \\
APh $(\mathrm{U} / \mathrm{L})$ & $177.2 \pm 162.6$ & $140.8 \pm 63.0$ \\
Total bilirubin (mg/dL) & $2.6 \pm 1.6$ & $2.2 \pm 1.5$ \\
Albumin $(\mathrm{g} / \mathrm{dL})$ & $3.0 \pm 0.6$ & $3.4 \pm 0.7$ \\
Creatinin $(\mathrm{mg} / \mathrm{dL})$ & $1.2 \pm 0.8$ & $1.1 \pm 0.3$ \\
$\alpha$-fetoprotein $(\mathrm{ng} / \mathrm{mL})$ & $23.0 \pm 47.1$ & $106.5 \pm 328.7$ \\
INR & $1.5 \pm 0.4$ & $1.4 \pm 0.4$ \\
\hline
\end{tabular}

AST = aspartate aminotransferase; ALT = alanine aminotransferase; GGT = $\gamma$-glutamyl transpeptidase; $\mathrm{APh}=$ alkaline phosphatase; INR = prothrombin time expressed as international normalized ratio. There was no statistically significant difference between groups (Mann-Whitney test). 
Table 2. Stratification of the $\alpha$-fetoprotein results for HCV-infected patients with liver cirrhosis with and without hepatocellular carcinoma (HCC).

\begin{tabular}{lcc}
\hline$\alpha$-fetoprotein $(\mathrm{ng} / \mathrm{mL})$ & $\begin{array}{c}\text { Without HCC } \\
(\mathrm{N}=33)\end{array}$ & $\begin{array}{c}\text { With HCC } \\
(\mathrm{N}=17)\end{array}$ \\
\hline $0-9$ & $23 / 33(69.7 \%)$ & $9 / 17(52.9 \%)$ \\
$10-99$ & $8 / 33(24.2 \%)$ & $6 / 17(35.3 \%)$ \\
$\geq 100$ & $2 / 33(6 \%)$ & $2 / 17(11.7 \%)$
\end{tabular}

There was no statistically significant difference between groups (Mann-Whitney test).

Table 3. Serological hepatitis B virus (HBV) markers of HCVinfected patients with liver cirrhosis with and without hepatocellular carcinoma (HCC).

\begin{tabular}{lcc}
\hline & $\begin{array}{c}\text { Without HCC } \\
(\mathrm{N}=33)\end{array}$ & $\begin{array}{c}\text { With HCC } \\
(\mathrm{N}=17)\end{array}$ \\
\hline Total anti-HBC (isolated) & $4 / 33(12.1 \%)$ & $3 / 17(17.6 \%)$ \\
Total anti-HBC and anti-HBs & $3 / 33(9.0 \%)$ & $2 / 17(11.7 \%)$ \\
No HBV markers & $22 / 33(66.7 \%)$ & $11 / 17(64.0 \%)$ \\
Anti-HBs (isolated) & $4 / 33(12.1 \%)$ & $1 / 17(5.8 \%)$ \\
\hline
\end{tabular}

Anti-HBc = anti-hepatitis B core antigen; anti-HBs = anti-hepatitis $B$ surface antigen. There was no statistically significant difference between groups (Yates corrected chi-square or Fisher exact tests).

Table 4. Hepatitis C virus (HCV) genotypes found in HCV-infected patients with liver cirrhosis with and without hepatocellular carcinoma (HCC).

\begin{tabular}{lclc}
\hline $\begin{array}{l}\text { HCV } \\
\text { genotype }\end{array}$ & $\begin{array}{c}\text { Without HCC } \\
(\mathrm{N}=24)\end{array}$ & $\begin{array}{c}\text { With HCC } \\
(\mathrm{N}=15)\end{array}$ & Total \\
\hline 1 & $15 / 24(60.0 \%)$ & $6 / 15(40.0 \%)$ & $21 / 39(53.7 \%)$ \\
2 & 0 & $1 / 15(6.7 \%)$ & $1 / 39(2.6 \%)$ \\
3 & $9 / 24(40.0 \%)$ & $8 / 15(53.3 \%)$ & $17 / 39(43.7 \%)$
\end{tabular}

There was no statistically significant difference between groups (Yates corrected chi-square or Fisher exact tests).

Table 5. Hepatitis B virus DNA (HBV DNA) detection in serum and liver tissue by real time PCR in HCV-infected patients with liver cirrhosis with and without hepatocellular carcinoma (HCC).

\begin{tabular}{lcc}
\hline HBV DNA & $\begin{array}{c}\text { Without HCC } \\
(\mathrm{N}=33)\end{array}$ & $\begin{array}{r}\text { With HCC } \\
(\mathrm{N}=17)\end{array}$ \\
\hline Serum & $0 / 33$ & $1 / 17$ \\
Tumoral tissue & $\mathrm{NA}$ & $0 / 17$ \\
Non-tumoral tissue & $0 / 33$ & $0 / 17$ \\
\hline
\end{tabular}

There was no statistically significant difference between groups (Fisher exact test). NA = not applicable.
HCV RNA was detected and genotyped in 39 serum samples. Due to samples storage at $-20^{\circ} \mathrm{C}$, in some of them it was not possible to extract viral RNA for genotyping, as shown in Table 4 . In group 1 there was a predominance of genotype $1 \mathrm{HCV}$ infection (60.0\%) while in group 2 genotype non-1 HCV was more frequent (9/15, 60.0\%), mainly genotype 3 . These differences were not statistically significant.

HBV DNA detection in serum and in tumoral and nontumoral liver tissues was carried out by RT-PCR. Results are shown in Table 5. In two liver tissue samples it was not possible to amplify the internal control DNA ( $\beta$ actin) due to PCR inhibition and therefore they could not be used to evaluate the presence of HBV DNA.

There was only one positive sample in the serum from a 66-year-old male patient with isolated total anti-HBc and HCC and with two grade II hepatic neoplastic nodules according to the Edmondson and Steiner classification and HCV genotype 1.

\section{Discussion}

The frequency of occult HBV infection was very low in the cirrhotic Brazilian patients followed up in São Paulo with or without HCC studied here, since only one serum sample and none of the liver tissues were HBV DNA positive. The prevalence of occult infection seems to be closely related to the prevalence of HBV infection in different parts of the world. Several investigators have shown an intermediate to high occurrence of HBV occult infection, both in serum and in liver tissue (1,2,4,8-15). In Brazil, particularly in the Southeast region, the prevalence of HBV infection is very low (21) and this may have contributed to our results of an HBV occult infection rate close to zero. A recent study involving Chinese patients reported a high rate (10/19) of false-positive HBV DNA by PCR in patients with hepatitis $B$ core antibody (anti-HBc) alone. Thus, a highly sensitive and specific HBV PCR amplification assay is essential to determine the prevalence of occult HBV infection (34).

It is noteworthy that we only detected HBV DNA in one serum sample and in none of the liver samples. This finding is probably related to the fact that the small liver biopsy fragment analyzed by us did not contain viral particles that might be found in other liver fragments. Another possible explanation is that we analyzed only paraffinembedded fragments and perhaps a higher sensitivity could have been achieved if we had analyzed fresh liver fragments immediately transferred to a DNA-conserving storage solution. To decrease the impact of false-negative results due to inhibition of amplification, HBV DNA amplifi- 
cation results were considered only if the household gene was also amplified from the same liver fragment.

Group comparison for age showed that HCC occurred in older cirrhotic patients, as previously reported (35).

HCV genotype 1 was the most frequent in group 1 patients, while non-1 genotypes (mainly genotype 3 ) were more frequent in group 2. The association of HCV genotypes and the development of HCC is controversial. Some investigators did not find any association between HCC and HCV genotypes (36) while other reports have associated genotype $1 \mathrm{~b}$ with $\mathrm{HCC}$ development (37). Despite the finding of genotype $1 \mathrm{~b}$ as the most frequent in $\mathrm{HCC}$ in some world regions, some investigators could not establish a definitive association since this genotype was the most prevalent in their countries (38). Concerning this point, it is very interesting that the results in the present study showed HCV genotype 3 as the more frequent among HCC cases but this genotype is not the most frequent in Brazil (29).

An extensive search of the scientific databases revealed that data on the frequency of $\mathrm{HCV}$ genotypes in Brazilian HCC patients have not been published before. To our knowledge, this is the first study devoted to the determination of HCV genotypes in Brazilian HCC patients and our results highlight the need for more studies on the frequency of HCV genotypes in HCC in Brazil. HCV shows a high divergence due to the absence of a proofreading enzyme during its replication and it is possible that HCV genotype 3 found in Brazil has particular genetic features

\section{References}

1. Hu KQ. Occult hepatitis B virus infection and its clinical implications. J Viral Hepat 2002; 9: 243-257.

2. Brechot $C$, Thiers $V$, Kremsdorf D, Nalpas B, Pol S, PaterliniBrechot $P$. Persistent hepatitis $B$ virus infection in subjects without hepatitis $B$ surface antigen: clinically significant or purely "occult"? Hepatology 2001; 34: 194-203.

3. Hou J, Wang Z, Cheng J, Lin Y, Lau GK, Sun J, et al. Prevalence of naturally occurring surface gene variants of hepatitis $B$ virus in nonimmunized surface antigen-negative Chinese carriers. Hepatology 2001; 34: 1027-1034.

4. Tamori A, Nishiguchi S, Kubo S, Enomoto M, Koh N, Takeda $T$, et al. Sequencing of human-viral DNA junctions in hepatocellular carcinoma from patients with $\mathrm{HCV}$ and occult HBV infection. J Med Virol 2003; 69: 475-481.

5. Murakami $Y$, Minami M, Daimon Y, Okanoue T. Hepatitis B virus DNA in liver, serum, and peripheral blood mononuclear cells after the clearance of serum hepatitis B virus surface antigen. J Med Virol 2004; 72: 203-214.

6. Yotsuyanagi H, Yasuda K, Moriya K, Shintani Y, Fujie H, Tsutsumi $T$, et al. Frequent presence of HBV in the sera of that link it to a carcinogenetic pathway. Sequencing of other genomic regions such as C, NS3 and NS5A, coding for antigens previously related to HCC development, (39) will help elucidate this issue.

The two groups were similar regarding biochemical and coagulation markers and MELD score, since all patients were cirrhotics waiting for liver transplantation. Serum $\alpha$-fetoprotein levels were also similar for the two groups due to the predominance of early and small HCC (40) as a consequence of the active screening for this malignant disease in cirrhotic patients by our group. Evaluation of the Child-Turcot Classification modified by Pugh showed a statistically significant difference due to the presence of four patients with child $A$ in group 2. Child $A$ level patients were referred for transplantation due to early detection of HCC.

In conclusion, a very low occult HBV infection rate $(0.5 \%)$ was found in cirrhotic HCV patients with or without HCC. Only one case with HCC among 17 showed occult HBV infection detected in serum. These results are probably related to the low prevalence of HBV infection in our population. Furthermore, we have also shown that $\mathrm{HCV}$ genotype 3 is frequently found in Brazilian cirrhotic patients, particularly when they also have HCC. More studies involving a large number of cases should be carried out to confirm these data and to further characterize Brazilian $\mathrm{HCV}$ genotype isolates to elucidate genetic features that might be related to its carcinogenic potential.
HBsAg-negative, anti-HBc-positive blood donors. Transfusion 2001; 41: 1093-1099.

7. Rumi MG, Colombo M, Romeo R, Colucci G, Gringeri A, Mannucci PM. Serum hepatitis B virus DNA detects cryptic hepatitis $B$ virus infections in multitransfused hemophilic patients. Blood 1990; 75: 1654-1658.

8. Cacciola I, Pollicino T, Squadrito G, Cerenzia G, Orlando $\mathrm{ME}$, Raimondo $\mathrm{G}$. Occult hepatitis B virus infection in patients with chronic hepatitis $\mathrm{C}$ liver disease. N Engl J Med 1999; 341: 22-26.

9. Cacciola I, Pollicino T, Squadrito G, Cerenzia G, Villari D, de Franchis R, et al. Quantification of intrahepatic hepatitis B virus (HBV) DNA in patients with chronic HBV infection. Hepatology 2000; 31: 507-512.

10. Rodriguez-Inigo E, Mariscal L, Bartolome J, Castillo I, Navacerrada C, Ortiz-Movilla N, et al. Distribution of hepatitis $B$ virus in the liver of chronic hepatitis $C$ patients with occult hepatitis B virus infection. J Med Virol 2003; 70: 571580.

11. De Maria N, Colantoni A, Friedlander L, Leandro G, Idilman 
$\mathrm{R}$, Harig J, et al. The impact of previous HBV infection on the course of chronic hepatitis C. Am J Gastroenterol 2000; 95: 3529-3536.

12. Giannini E, Ceppa P, Botta F, Fasoli A, Romagnoli P, Ansaldi $F$, et al. Previous hepatitis $B$ virus infection is associated with worse disease stage and occult hepatitis $B$ virus infection has low prevalence and pathogenicity in hepatitis $C$ virus-positive patients. Liver Int 2003; 23: 12-18.

13. Squadrito G, Orlando ME, Pollicino T, Raffa G, Restuccia T, Cacciola I, et al. Virological profiles in patients with chronic hepatitis $\mathrm{C}$ and overt or occult HBV infection. Am J Gastroenterol 2002; 97: 1518-1523.

14. Kao JH, Chen PJ, Lai MY, Chen DS. Occult hepatitis B virus infection and clinical outcomes of patients with chronic hepatitis C. J Clin Microbiol 2002; 40: 4068-4071.

15. Fabris P, Brown D, Tositti G, Bozzola L, Giordani MT, Bevilacqua $P$, et al. Occult hepatitis $B$ virus infection does not affect liver histology or response to therapy with interferon alpha and ribavirin in intravenous drug users with chronic hepatitis C. J Clin Virol 2004; 29: 160-166.

16. Shiota G, Oyama K, Udagawa A, Tanaka K, Nomi T, Kitamura A, et al. Occult hepatitis B virus infection in HBs antigen-negative hepatocellular carcinoma in a Japanese population: involvement of HBx and p53. J Med Virol 2000; 62: 151-158.

17. Ding X, Park YN, Taltavull TC, Thung SN, Jin X, Jin $Y$, et al. Geographic characterization of hepatitis virus infections, genotyping of hepatitis B virus, and p53 mutation in hepatocellular carcinoma analyzed by in situ detection of viral genomes from carcinoma tissues: comparison among six different countries. Jpn J Infect Dis 2003; 56: 12-18.

18. Tamori A, Nishiguchi S, Kubo S, Narimatsu T, Habu D, Takeda T, et al. HBV DNA integration and HBV-transcript expression in non-B, non-C hepatocellular carcinoma in Japan. J Med Virol 2003; 71: 492-498.

19. Ohba K, Kubo S, Tamori A, Hirohashi K, Tanaka H, Shuto T, et al. Previous or occult hepatitis $B$ virus infection in hepatitis B surface antigen-negative and anti-hepatitis C-negative patients with hepatocellular carcinoma. Surg Today 2004; 34: 842-848.

20. Allain JP. Occult hepatitis B virus infection. Transfus Clin Biol 2004; 11: 18-25.

21. Carrilho FJ, Corrêa MCJM. Magnitude of hepatitis $B$ and $C$ in Latin America. In: Schinazi RF, Sommadossi JP, Thomas HC (Editors), Therapies for viral hepatitis. Atlanta: International Medical Press; 1998. p 25-34.

22. Santos EA, Yoshida CF, Rolla VC, Mendes JM, Vieira IF, Arabe $\mathrm{J}$, et al. Frequent occult hepatitis $\mathrm{B}$ virus infection in patients infected with human immunodeficiency virus type 1. Eur J Clin Microbiol Infect Dis 2003; 22: 92-98.

23. Goncales FL Jr, Pereira JS, Da Silva C, Thomaz GR, Pavan $\mathrm{MH}$, Fais VC, et al. Hepatitis B virus DNA in sera of blood donors and of patients infected with hepatitis $C$ virus and human immunodeficiency virus. Clin Diagn Lab Immunol 2003; 10: 718-720.

24. Souza LO, Pinho JR, Carrilho FJ, da Silva LC. Absence of hepatitis $B$ virus DNA in patients with hepatitis $C$ and non-AE hepatitis in the State of São Paulo, Brazil. Braz J Med Biol Res 2004; 37: 1665-1668.

25. Edmondson HA, Steiner PE. Primary carcinoma of the liver: a study of 100 cases among 48,900 necropsies. Cancer 1954; 7: 462-503.

26. Kamath PS, Wiesner RH, Malinchoc M, Kremers W, Therneau TM, Kosberg CL, et al. A model to predict survival in patients with end-stage liver disease. Hepatology 2001; 33: $464-470$

27. Infante-Rivard C, Esnaola S, Villeneuve JP. Clinical and statistical validity of conventional prognostic factors in predicting short-term survival among cirrhotics. Hepatology 1987; 7: 660-664.

28. Chomczynski P, Sacchi N. Single-step method of RNA isolation by acid guanidinium thiocyanate-phenol-chloroform extraction. Anal Biochem 1987; 162: 156-159.

29. Campiotto S, Pinho JR, Carrilho FJ, da Silva LC, Souto FJ, Spinelli V, et al. Geographic distribution of hepatitis $C$ virus genotypes in Brazil. Braz J Med Biol Res 2005; 38: 41-49.

30. Dakhama A, Macek V, Hogg JC, Hegele RG. Amplification of human beta-actin gene by the reverse transcriptasepolymerase chain reaction: implications for assessment of RNA from formalin-fixed, paraffin-embedded material. $J$ Histochem Cytochem 1996; 44: 1205-1207.

31. Sitnik R, Pinho JR, Bertolini DA, Bernardini AP, da Silva LC, Carrilho FJ. Hepatitis B virus genotypes and precore and core mutants in Brazilian patients. J Clin Microbiol 2004; 42: 2455-2460.

32. Pinho JR, Santos CA, Gonzalez CL, Bassit L, Barreto CC, Saez-Alquezar A, et al. Detection of hepatitis B virus DNA by the polymerase chain reaction in anti-HBe positive chronic hepatitis B patients. Rev Inst Med Trop São Paulo 1993; 35: 515-520.

33. Statistical Package for Social Sciences (SPSS). [Computer program]. Version 12.0. Chicago: SPSS Inc.; 2006.

34. Khristova M, Nainan O, Xia GL. False positive HBV DNA results among persons with only antibody to hepatitis $B$ core antigen. Antiviral Ther 2000; 5 (Suppl 1): B22 (Abstract).

35. Bruix J, Sherman M. Management of hepatocellular carcinoma. Hepatology 2005; 42: 1208-1236.

36. Fattovich G, Ribero ML, Pantalena M, Diodati G, Almasio P, Nevens F, et al. Hepatitis $C$ virus genotypes: distribution and clinical significance in patients with cirrhosis type $C$ seen at tertiary referral centres in Europe. $J$ Viral Hepat 2001; 8: 206-216.

37. Lee CM, Lu SN, Hung CH, Tung WC, Wang JH, Tung HD, et al. Hepatitis $\mathrm{C}$ virus genotypes in southern Taiwan: prevalence and clinical implications. Trans $R$ Soc Trop Med Hyg 2006; 100: 767-774

38. Lopez-Labrador FX, Ampurdanes S, Forns X, Castells A, Saiz JC, Costa J, et al. Hepatitis C virus (HCV) genotypes in Spanish patients with HCV infection: relationship between HCV genotype 1b, cirrhosis and hepatocellular carcinoma. J Hepatol 1997; 27: 959-965.

39. Anzola M. Hepatocellular carcinoma: role of hepatitis B and hepatitis $C$ viruses proteins in hepatocarcinogenesis. J Viral Hepat 2004; 11: 383-393.

40. Trevisani F, D'Intino PE, Morselli-Labate AM, Mazzella G, Accogli E, Caraceni $P$, et al. Serum alpha-fetoprotein for diagnosis of hepatocellular carcinoma in patients with chronic liver disease: influence of $\mathrm{HBsAg}$ and anti-HCV status. J Hepatol 2001; 34: 570-575. 